Books by W. S. Di Piero

\author{
POEMS \\ The First Hour \\ The Only Dangerous Thing \\ Early Light \\ The Dog Star
}

$\longrightarrow$

TRANSLATIONS

Pensieri, by Giacomo Leopardi

This Strange Joy: Selected Poems of Sandro Penna

The Ellipse: Selected Poems of Leonardo Sinisgalli

ESSAYS

Memory and Enthusiasm: Essays, 1975-1985

Out of Eden: Essays on Modern Art 
OUT OF EDEN 


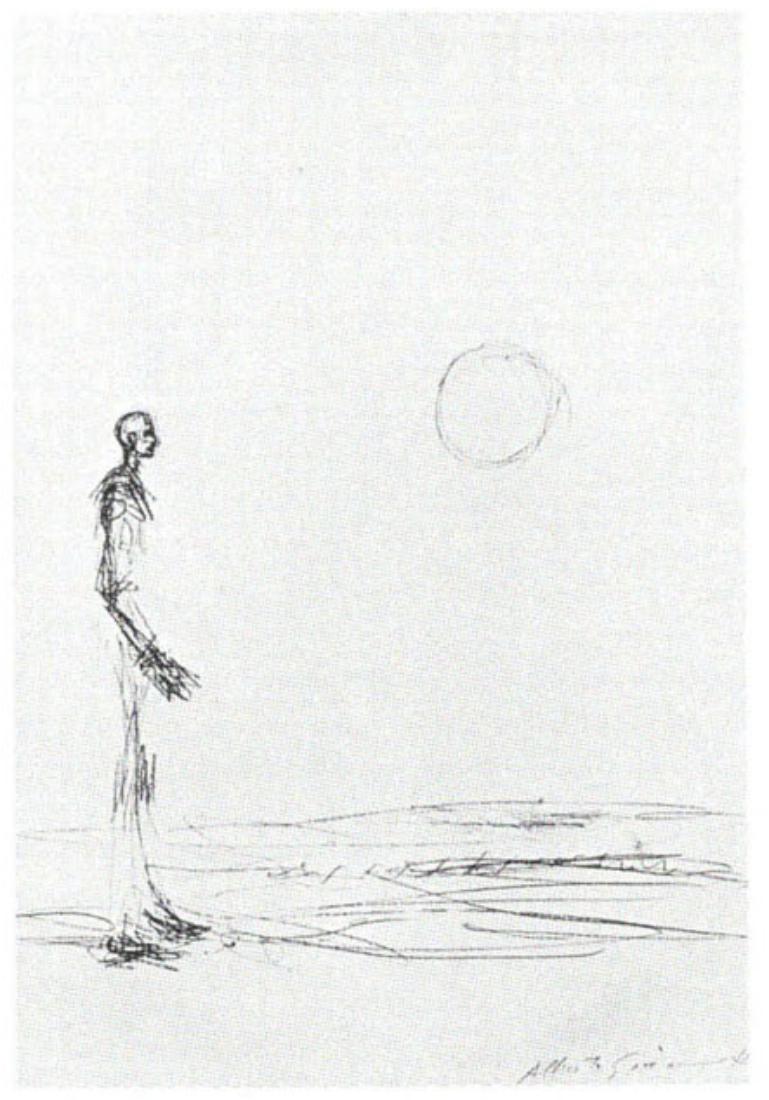

Frontispiece. Alberto Giacometti, Standing Man and Sun, 1963. Lithograph, $47 \times 37 \mathrm{~cm}$ (183/10 $\times 14^{2 / 5}$ inches).

Collection Fondation Pierre Gianadda, Martigny, Switzerland. 


\section{OUT OF EDEN}

\section{Essays on Modern Art}

\section{W. S. Di Piero}


The publishers wish to acknowledge with gratitude the contribution provided from the Art Book Fund of the Associates of the University of California Press, which is supported by a major gift of the Ahmanson Foundation.

\author{
University of California Press \\ Berkeley and Los Angeles, California \\ University of California Press, Ltd. \\ Oxford, England \\ (C) I99I by \\ The Regents of the University of California
}

LIBRARY OF CONGRESS

CATALOGING-IN-PUBLICATION DATA

Di Piero, W. S.

Out of Eden : essays on modern art / W. S. Di Piero.

p. $\mathrm{cm}$.

Includes bibliographical references and index.

ISBN 0-520-07065-8 (cloth)

I. Art, Modern-2oth century-Themes, motives.

I. Title.

N6490.D44 I99I

$709^{\prime} .04-\mathrm{dc} 20$

$90-48336$

Printed in the United States of America

$\begin{array}{lllllllll}\text { I } & 2 & 3 & 4 & 5 & 6 & 7 & 8 & 9\end{array}$

The paper used in this publication meets the minimum requirements of American National Standard for Information Sciences-Permanence of Paper for Printed Library Materials, ANSI Z39-48-I984. 
Cézanne discovered that it's impossible to copy nature. You can't do it. But one must try all the same. Try-like

Cézanne-to translate one's sensation.

ALBERTO GIACOMETTI 
